\title{
Research on the optimization of DCS sound and light alarm function
}

\author{
Mingming Bian ${ }^{1, a}$, Qiang Guo ${ }^{1, b}$ Xiaona Sun ${ }^{2, c}$, Lijian Zhang ${ }^{1, d}$ and \\ Xiaojun Yang ${ }^{3, d}$ \\ ${ }^{1}$ Binzhou Polytechnic, Shandong, China \\ ${ }^{2}$ Shan Dong Heng Tai Group, Shandong, China \\ ${ }^{3}$ Shan Dong Befar Group, Shandong, China

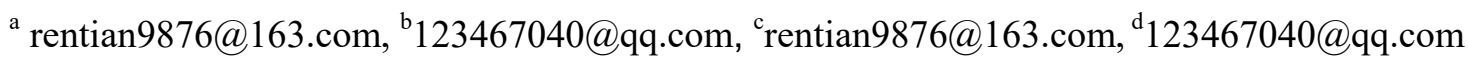

\begin{abstract}
In this study, a sound and light alarm function optimization scheme was put forward and successful implemented by the application of DCS sound and light alarm function. Using the function optimization scheme, the existing problems in sound and light alarm functions were deeply analyzed and well solved. The development of the optimization scheme made an innovation on the function of DCS control system, and greatly ensured the safe and economic operation of the production plant.
\end{abstract}

Keywords: DCS, Sound and light alarm, Optimization.

\section{Introduction}

As an example of DCS based on a company, the company's master control room used machine, furnace, electric integration design scheme, the operators of the boiler, turbine, in the same central control room to control the production process and operation. Master control room DCS control system is divided into two periods, the first phase of the operation of the DCS configuration station are: the boiler No. 1, boiler No. 2, turbine No. 1, turbine No. 2 and turbine public part. Voice alarm is in two different kinds of sound through the two buzzers. The second phase DCS is equipped with a speaker at the operation station of boiler No.3 and turbine No. 3, using different music to alert the alarm. In addition, DCS has two alarm sound boxes in the electric backstage, achieving six kinds of sound alarm type. It is difficult to distinguish at the first time produce alarm device through different sound effects and music, delaying the timeliness of the operation, with a great influence on the security and stability and economic operation. It is of great significance to improve the sound and light alarm function of DCS.

\section{Problems and improvement of DCS sound alarm system}

For reason of no normal use of DCS sound and light alarm, five aspects from point parameters, acoustics, alarm screen, the configuration logic, using method and so on are analyzed. The analysis and discussion of various reasons.1It has too many parameters and more alarm value setting.2The buzzer is too loud and can't be adjusted to affect the normal monitoring operation. 3It is difficult to distinguish the sound from the ringtone of the mobile phone and alarm.4Alarm parameters are distributed in all flowchart images and difficult to find. 5Alarm parameter state display is relatively simle. 6Because of the configuration of boiler 1 and No. 2 and the configuration of the 1 and 2 turbine are in a collision course, there is a conflict. 7 No consideration is given to the normal and failure of the parameters, when the device may also be stopped and overhauled. 8The operation instructions are required to guide the operators to use.

\section{Reason analysis and determination}

Reason analysis. For reason of no normal use of DCS sound and light alarm, five aspects from point parameters, acoustics, alarm screen, the configuration logic, using method and so on are analyzed. The analysis and discussion of various reasons.It has too many parameters and more alarm 
value setting. The buzzer is too loud and can't be adjusted to affect the normal monitoring operation. It is difficult to distinguish the sound from the ringtone of the mobile phone and alarm.Alarm parameters are distributed in all flowchart images and difficult to find. Alarm parameter state display is relatively simle. Because of the configuration of boiler 1 and No. 2 and the configuration of the 1 and 2 turbine are in a collision course, there is a conflict. No consideration is given to the normal and failure of the parameters, when the device may also be stopped and overhauled. The operation instructions are required to guide the operators to use.

Determination. After deep analysis of the influencing factors, the alarm standard was discussed, and verification was confirmed, and the conclusion was shown in table 1.

\section{Table1 Conclusion}

\begin{tabular}{|c|c|c|c|c|}
\hline No. & Factors & Standard & Verification & Conclusion \\
\hline 1 & $\begin{array}{l}\text { It has too many } \\
\text { parameters and more } \\
\text { alarm value setting. }\end{array}$ & $\begin{array}{l}\text { The function of alarm is to prompt the } \\
\text { process operator to pay attention to the } \\
\text { change of parameter values, and } \\
\text { intervene timely when necessary. }\end{array}$ & $\begin{array}{l}\text { A parameter has four alarms: high and } \\
\text { high, high, low, low and low,causing } \\
\text { twice, especially in the case of abnormal } \\
\text { parameters. Too many parameters are } \\
\text { not targeted, resulting in the failure to } \\
\text { use the sound light alarm. }\end{array}$ & key \\
\hline 2 & $\begin{array}{l}\text { The buzzer is too loud } \\
\text { and can't be adjusted } \\
\text { to affect the normal } \\
\text { monitoring operation. }\end{array}$ & $\begin{array}{l}\text { In the case of noisy environment, the } \\
\text { volume can be helpful to distinguish } \\
\text { the alarm, which may have a certain } \\
\text { effect on the shift of shift operator. } \\
\text { The second phase of the use of the } \\
\text { dedicated speakers did not solve the } \\
\text { problem. }\end{array}$ & $\begin{array}{l}\text { Once produce overweight or abnormal } \\
\text { conditions, process operation personnel } \\
\text { must be conducted in the first place } \\
\text { corresponding adjustment, not only rely } \\
\text { on the personnel on duty to monitor the } \\
\text { quality, also want to make good use of } \\
\text { the third eye and ear. }\end{array}$ & Not the key \\
\hline 3 & $\begin{array}{l}\text { It is difficult to } \\
\text { distinguish the sound } \\
\text { from the ringtone of } \\
\text { the mobile phone and } \\
\text { alarm. }\end{array}$ & $\begin{array}{l}\text { Alarm sound should have special, } \\
\text { outstanding characteristics, can clearly } \\
\text { distinguish the alarm production of } \\
\text { production device, and timely } \\
\text { intervene. }\end{array}$ & $\begin{array}{l}\text { At present, mobile phone ring tones are } \\
\text { very rich, easy to be confused with the } \\
\text { sound box, up to } 6 \text { kinds. All flowchart } \\
\text { images have the light alarm, which is } \\
\text { synchronized with the sound alarm, but } \\
\text { the light alarm can only play an auxiliary } \\
\text { role, which is not as alert as the sound. }\end{array}$ & key \\
\hline 4 & $\begin{array}{l}\text { Alarm parameters are } \\
\text { distributed in all } \\
\text { flowchart images, } \\
\text { difficult to find. }\end{array}$ & $\begin{array}{l}\text { The alarm is issued at the first time to } \\
\text { find the alarm,by one-step clearly } \\
\text { indicating the alarm setting value }\end{array}$ & $\begin{array}{l}\text { In the past, all kinds of alarms are } \\
\text { together, and when multiple alarm } \\
\text { contents are generated at the same time, } \\
\text { it is impossible to distinguish the } \\
\text { parameters that generate the latest alarm. }\end{array}$ & key \\
\hline 5 & $\begin{array}{l}\text { Alarm parameter state } \\
\text { display is relatively } \\
\text { simle. }\end{array}$ & $\begin{array}{l}\text { The display should be special, } \\
\text { prominent, clear, and easy to observe. }\end{array}$ & $\begin{array}{l}\text { Only color changes, sometimes a } \\
\text { number of parameters is in the alarm } \\
\text { limit at the same time, can not } \\
\text { distinguish the latest alarm parameters. }\end{array}$ & Not the key \\
\hline 6 & $\begin{array}{l}\text { Because of the } \\
\text { configuration of boiler } \\
1 \text { and No. } 2 \text { and the } \\
\text { configuration of the } 1 \\
\text { and } 2 \text { turbine are in a } \\
\text { collision course, there } \\
\text { is a conflict. }\end{array}$ & $\begin{array}{l}\text { Ensure that the alarm of each set of } \\
\text { production units is independent, and } \\
\text { can give the corresponding prompt } \\
\text { sound when the alarm is produce. }\end{array}$ & $\begin{array}{l}\text { The alarm configuration of No. } 1 \text { and } \\
\text { No. } 2 \text { boilers exist in the same alarm } \\
\text { logic, } 1 \text { boiler maintenance or parameter } \\
\text { failure affects the normal operation and } \\
\text { operation of boiler } 2 \text {. }\end{array}$ & Not the key \\
\hline 7 & $\begin{array}{l}\text { No consideration is } \\
\text { given to the normal } \\
\text { and failure of the } \\
\text { parameters, when the } \\
\text { device may also be } \\
\text { stopped and } \\
\text { overhauled. }\end{array}$ & $\begin{array}{l}\text { Ensure that the alarm of each set of } \\
\text { production units is independent, and } \\
\text { can give the corresponding prompt } \\
\text { sound when the alarm is produce. }\end{array}$ & $\begin{array}{l}\text { The alarm configuration of No. } 1 \text { and } \\
\text { No. } 2 \text { boilers exist in the same alarm } \\
\text { logic, } 1 \text { boiler maintenance or parameter } \\
\text { failure affects the normal operation and } \\
\text { operation of boiler } 2 .\end{array}$ & Not the key \\
\hline 8 & $\begin{array}{l}\text { The operation } \\
\text { instructions are } \\
\text { required to guide the } \\
\text { operators to use }\end{array}$ & $\begin{array}{l}\text { The alarm function should be } \\
\text { mastered and used by the process } \\
\text { operator. The function of the alarm is } \\
\text { properly used in the standard and } \\
\text { reasonable operation. }\end{array}$ & $\begin{array}{l}\text { The process operator is not familiar with } \\
\text { the use method w when the alarm is } \\
\text { muffled and the parameters are } \\
\text { confirmed. In this regard, specific } \\
\text { operation instructions should be given } \\
\text { to guide use. }\end{array}$ & Not the key \\
\hline
\end{tabular}

After confirmation, the sound and light alarm can not be used. 1It has too many parameters and more alarm value setting.2The buzzer is too loud and can't be adjusted to affect the normal monitoring operation. 3It is difficult to distinguish the sound from the ringtone of the mobile phone and 
alarm.4Alarm parameters are distributed in all flowchart images and difficult to find. 5Alarm parameter state display is relatively simle. 6Because of the configuration of boiler 1 and No. 2 and the configuration of the 1 and 2 turbine are in a collision course, there is a conflict. 7No consideration is given to the normal and failure of the parameters, when the device may also be stopped and overhauled. 8The operation instructions are required to guide the operators to use. For the main reasons, it is import to focus on finding the feasible and optimal Countermeasures in terms of alarm parameters and alarm settings, alarm tones, and displaying alarm parameters in an alarm screen.

The formulation of measures. On the basis of the above reasons, the corresponding countermeasures are formulated after discussion and determination, as shown in Table 2.

Table2 Countermeasures

\begin{tabular}{|c|c|c|c|}
\hline Main cause & Present situation & Target & Measures \\
\hline $\begin{array}{l}\text { It has too many } \\
\text { parameters and } \\
\text { more alarm value } \\
\text { setting. }\end{array}$ & $\begin{array}{l}\text { The parameter alarm plan for boiler No. } \\
1-3 \text { and No. 1-3 is done according to the } \\
\text { requirements of trial run. The } \\
\text { characteristic is that the coverage is } \\
\text { large, the content of the alarm is all, and } \\
\text { one parameter even has } 4 \text { alarms. }\end{array}$ & $\begin{array}{l}\text { Let the parameters closely } \\
\text { related to the production and } \\
\text { operation enter the new alarm } \\
\text { plan, the alarm setting value has } \\
\text { the desired effect, so that the } \\
\text { operator can make } \\
\text { corresponding adjustment at the } \\
\text { first time. }\end{array}$ & $\begin{array}{l}\text { According to the actual } \\
\text { operation situation and the } \\
\text { experience of the operation } \\
\text { personnel, the alarm } \\
\text { parameters and set values } \\
\text { are rechecked, and the } \\
\text { adjustment is made in time. }\end{array}$ \\
\hline $\begin{array}{l}\text { It is difficult to } \\
\text { distinguish the } \\
\text { sound from the } \\
\text { ringtone of the } \\
\text { mobile phone and } \\
\text { alarm. }\end{array}$ & $\begin{array}{l}\text { There are two different sounded buzzer, } \\
\text { two sound box music, plus the other two } \\
\text { alarm sound boxes. There are } 6 \text { kinds of } \\
\text { alarm in the main control room, and the } \\
\text { music of the sound box is very easy to } \\
\text { confuse with the phone ring. }\end{array}$ & $\begin{array}{l}\text { The alarm is easy to distinguish, } \\
\text { clear, accurate, and let the } \\
\text { operator get a very clear warning } \\
\text { at the first time. }\end{array}$ & $\begin{array}{l}\text { A voice alarm is used to } \\
\text { prompt a device to alarm } \\
\text { and reminding the alarm } \\
\text { parameters. }\end{array}$ \\
\hline $\begin{array}{l}\text { Alarm parameters } \\
\text { are distributed in } \\
\text { all flowchart } \\
\text { images, difficult to } \\
\text { find. }\end{array}$ & $\begin{array}{l}\text { Previous application control system's } \\
\text { own alarm screen, because it is the alarm } \\
\text { summary, all kinds of alarms are all } \\
\text { together. It may produce multiple alarm } \\
\text { contents at the same time, and can not } \\
\text { distinguish the latest alarm parameters. }\end{array}$ & $\begin{array}{l}\text { The alarm is sent out at the first } \\
\text { time. Which parameter can be } \\
\text { found by one step, and the alarm } \\
\text { setting is clearly indicated. }\end{array}$ & $\begin{array}{l}\text { To increase the operation } \\
\text { picture for each set of } \\
\text { production units, the public } \\
\text { part of the steam turbine is } \\
\text { separated from the No. } 1-3 \\
\text { steam turbine and a separate } \\
\text { alarm picture is configured. }\end{array}$ \\
\hline
\end{tabular}

\section{Plan implementation and implementation effect}

The countermeasures are summarized, and the optimization scheme of DCS acoustooptic alarm function is put forward.

First, every flow chart shows the "view the alarm picture" button, and click to enter the alarm picture of the corresponding production device, as shown in Figure 1.

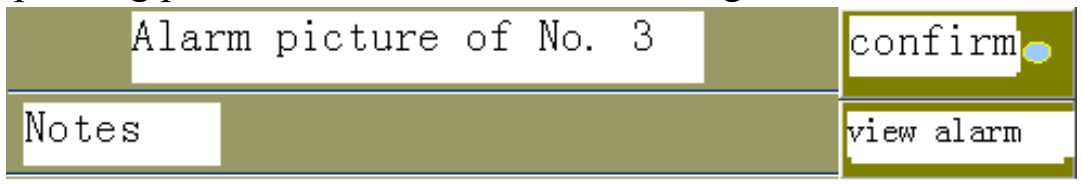

Fig.1 Alarm icon

Second, set the corresponding alarm confirmation button, which is used to muffle the alarm voice and reset the light alarm indicator, as shown in Figure 2.

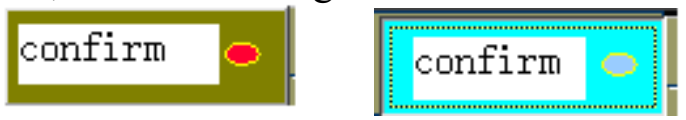

Fig.2 Alarm confirmation

Third, the "alarm screen" contains all the sound and light alarm parameters, and displays the specific high and low setting values. These alarm values are confirmed by the process professionals, as shown in Figure 3.

\begin{tabular}{|c||c|c|}
\hline Measuring point name & High value & Low value \\
\hline Drum pressure A & 10.8 & 8.6 \\
\hline
\end{tabular}


Fig.3 Parameters alarm

Fourth, in order to let operators see the alarm parameters more conveniently, the alarm state in the alarm screen can be distinguished by changing the color and scintillation two ways. It can distinctly distinguish the alarm parameters from the parameter color. as shown in Figure 4.

\begin{tabular}{|c|c|}
\hline Measuring point name & Measured value \\
\hline D Drum water level(middle) & $75.6 \mathrm{~mm}$ \\
\hline
\end{tabular}

Fig.4 Alarm parameters

Fifth, in view of the overhaul of the production equipments and parameters, the total alarm and switch of the 1-3 stove, the 1-3 engine and the turbine common device are set up separately, as shown in Figure 5. All the parameters are set up with input and resetting switch, as shown in Figure 6.

\begin{tabular}{|c|c|c|c|c|}
\hline Total alarm switch for $N$ & 3 boiler & & & Onof \\
\hline \multicolumn{5}{|c|}{ Fig.5 Alarm total switch } \\
\hline Steam collector pressure & 8. $7 \mathrm{MPa}$ & 9.8 & 8.5 & $\overline{O n}$ \\
\hline
\end{tabular}

Fig.6 Parameters switch

\section{Conclusion}

After in-depth analysis of the original DCS sound and light alarm function, summarizes the main reason of DCS alarm optimization, and to develop the effective implementation.Since the successful implementation of the scheme, it has been running effectively, improving the working efficiency and ensuring the safety, stability and economic operation of the device.

\section{Acknowledgements}

Fund Project: A Project of Binzhou Polytechnic Science and Technology Program (study on application of "Internet plus industrial control").

\section{References}

[1] Sun Zhijun. Applications of High and Low Water Level Acousto-optic Alarm Device in Central Pump[J]. Coal and Chemical Industry.2015[6].

[2] Jiang Yong, XUE Lian.Monitoring design for chemical auxiliary machines by sound and light alarm system[J].Huadian Technology.2012[10].

[3] Zhang Gailian.Design of Intelligent Alarm System for Fire Based on Microcontroller[J]. Application $\cdot$ Communication.2016[12].

[4] Zhao Shuchang,CAO Libo,REN Yudong. Design of Device for Coal Mine Safety Transportation with Voice andLight Alarm[J]. Coal Mine Machinery.2014[8].

[5] Sun Yancheng,WANG Yafei,ZHOU Ying,etc.A Design of Acousto-Optic Voice Linkage Alarm System[J]. Chinese Journal of Electron Devices.2011[10]. 